\title{
Study of the Effect of Different Industrial Coating with Microscale Thickness on the CK45 Steel by Experimental and Finite Element Methods
}

\author{
K. R. Kashyzadeh ${ }^{1}$ and A. $\operatorname{Arghavan}^{2}$ \\ Islamic Azad University, Semnan, Iran \\ ${ }^{1}$ kazem.kashyzadeh@gmail.com \\ 2 AlirezaArghavan@semnaniau.ac.ir
}

УДК 539.4

\section{Исследование влияния разных промышленных покрытий микро- размерной толщины на сталь СК45 с помощью экспериментального и конечноэлементного методов}

\author{
К. Р. Кашизадех, А. Аргаван
}

Исламский университет Азад, Семнан, Иран

\begin{abstract}
Анализируется влияние промышленных покрытий из упрочненного хрома, износостойкого хрома и упрочненного никеля, полученных методом горячего цчинкования, на предел выносливости деталей. Предпринята попытка более точно проанализировать усталость деталей посредством моделирования гранищы раздела между основным металлом и покрытием, используя при этом упругие элементы. Проведено сравнение кривых усталости, полученных представленным методом конечноэлементного моделирования (включая три различные фазы) и известными методами конечноэлементного моделирования, в которых для моделирования промежуточной фазы использовали элемент оболочки, с кривыми усталости, построенными по данным экспериментальных исследований. Результаты показали, что данная модель является усовершенствованной по сравнению с другими моделями и позволяет получить более надежные результаты. С учетом условий окружающей среды и эксплуатационных условий в качестве наиболее приемлемого покрытия представлено тонкое цинковое покрытие. При значительном увеличении толщины покрытия наилучшим вариантом является упрочненное хромовое покрытие. Увеличение толщчны оцинкованных и упрочненных хромовых покрытий на 6 мкм приводит к уменьшению значения предела выносливости на 14,96 и 4,37\% соответственно.
\end{abstract}

Ключевые слова: усталость, покрытие, упрочненный хром, оцинкованный, износостойкий хром, упрочненный никель, кривая усталости, конечноэлементная модель, промежуточная фаза.

Introduction. Under frequent and repeated tension, metal is broken by tensile stress, which is lower than the one required for fracture in static tension conditions. On the other hand, damage of component subjected to simultaneous action of fatigue and corrosion is much higher than that under consequent application of fatigue and corrosion conditions. In the latter situation, there is no clear change in the metal structure which is broken due to fatigue, which could be used as an evidence for recognition of the reasons of fatigue fracture. At least $90 \%$ of in-service component failures related to mechanical factors is fatigue [1]. 
According to the standards of fatigue testing presented by the Association of Mechanical Engineers of Japan in 1981 and by ASTM in 1998 for constructing an $S-N$ curve with the minimum number of test specimens, 14 test specimens are needed, 8 of which are used to determine the limited lifetime above the fatigue limit. Testing of two specimens at all four levels specifies the balance of the applied load. Also, the fatigue limit can be obtained by step-wise procedure with 6 test specimens.

Step-wise procedure, which is often referred to as the up-and-down method, is one of the most common ways that is consistent with most of the available criteria for evaluating the statistical properties of the fatigue limit $[2,3]$.

1. Obtaining the Mechanical Properties of the Components.

1.1. Preparing the Components. Ten cylindrical rod-shaped specimens of $12 \mathrm{~mm}$ in diameter and the length of $279 \mathrm{~mm}$ with the base metal CK45 are produced, according to tensile test standards, machined and subjected to surface treatment [4] for further deposition of each group of coatings under study.

At the final stage of preparation, analyzed coatings of various thickness are deposited under the same operation conditions, such as temperature, humidity and other factors [5].

1.2. Testing Conditions. In this study, tensile testing machine STM-600 is used in accordance with Fig. 1.

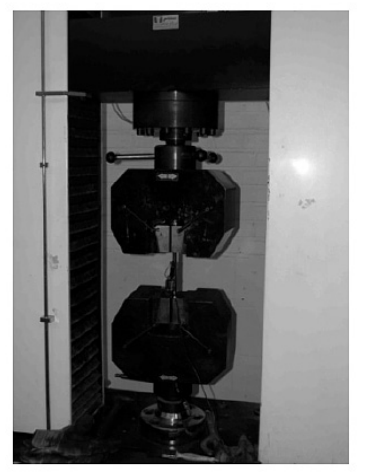

Fig. 1. Tensile testing machine.

1.3. Results. The stress-strain curves obtained from tensile tests for components with different coatings (industrial coatings under study) of 13 and $19 \mu \mathrm{m}$ in thickness are depicted in Fig. 2. In Tables 1 and 2, the mechanical characteristics of the components with coatings of 13 and $19 \mu \mathrm{m}$ in thickness obtained from tensile test are tabulated, respectively.

\section{Preparation of Components for Fatigue Tests.}

2.1. Number of Components Required. As it was mentioned earlier, according to the ASTM standard in 1998, the number of experimental components required to get the first component of the $S-N$ curve (limited lifetime above the fatigue limit) is equal to 8 specimens, however, in order to obtain more reliable results, 12 components have been used in experiment with 4 levels of applied cyclic load, 3 specimens being tested at each cyclic load level, so that the average fatigue life of 3 specimens is treated as the fatigue life at the respective cyclic load level. 
K. R. Kashyzadeh and A. Arghavan

$\mathrm{T}$ a b 1 e 1

Mechanical Properties of Components with a Thickness of $13 \mu \mathrm{m}$ [6]

\begin{tabular}{|c|c|c|c|c|c|c|}
\hline \multirow[t]{2}{*}{ Result } & \multicolumn{3}{|c|}{ Embellished chromium } & \multicolumn{3}{|c|}{ Hardened chromium } \\
\hline & Peak & Break & Yield & Peak & Break & Yield \\
\hline Force $(\mathrm{N})$ & 105392.9 & 87833.47 & 105193.9 & 107045.3 & 95098.09 & 106539.9 \\
\hline Extension (mm) & 1.810215 & 5.641043 & 1.478078 & 3.583356 & 6.912126 & 1.8323570 \\
\hline Stress $(\mathrm{MPa})$ & 931.8779 & 776.6183 & 930.1183 & 946.4883 & 840.8517 & 942.0194 \\
\hline Elongation & 3.62043 & 11.28209 & 2.956157 & 7.166711 & 13.82425 & 3.664713 \\
\hline Elongation after break & 3.457021 & 11.10079 & 2.792546 & 7.465292 & 13.8729 & 3.952722 \\
\hline Module (MPa) & 25739.43 & 6883.641 & 31463.77 & 13206.73 & 6082.439 & 25705.13 \\
\hline \multirow[t]{2}{*}{ Energy (kJ) } & 178.4 & 560.6 & 143.5 & 373.3 & 719.5 & 186.1 \\
\hline & \multicolumn{3}{|c|}{ Hardened nickel } & \multicolumn{3}{|c|}{ Warm galvanizing } \\
\hline Force $(\mathrm{N})$ & 110237.8 & 94113.62 & 109983.8 & 110415.8 & 95250.06 & 109962.8 \\
\hline Extension (mm) & 0.5746964 & 3.280554 & 0.3065699 & 3.450773 & 7.622701 & 1.608388 \\
\hline Stress $(\mathrm{MPa})$ & 974.7166 & 832.1472 & 972.4702 & 976.2899 & 842.1954 & 972.2845 \\
\hline Elongation & 1.149393 & 6.561108 & 0.6131397 & 6.901545 & 15.2454 & 3.216776 \\
\hline Elongation after break & 1.053799 & 6.477806 & 0.5177394 & 6.904699 & 15.21457 & 3.218915 \\
\hline Module (MPa) & 84802.73 & 12683.03 & 158605.0 & 14145.96 & 5524.259 & 30225.44 \\
\hline Energy (kJ) & 96.3 & 377.4 & 43.1 & 376.7 & 821.2 & 173.6 \\
\hline
\end{tabular}

T a b 1 e 2

Mechanical Properties of Components with a Thickness of $19 \mu \mathrm{m}$ [6]

\begin{tabular}{||l|c|c|c|c|c|c||}
\hline \multirow{2}{*}{ Result } & \multicolumn{2}{|c}{ Embellished chromium } & \multicolumn{3}{c||}{ Hardened chromium } \\
\cline { 2 - 7 } & Peak & Break & Yield & Peak & Break & Yield \\
\hline Force (N) & 103591.1 & 86814.84 & 103509.9 & 105971.7 & 97161.85 & 105877.5 \\
\hline Extension (mm) & 3.000181 & 6.830809 & 2.12211 & 0.1070035 & 0.055746 & 0.0906766 \\
\hline Stress (MPa) & 915.9464 & 767.6118 & 915.2288 & 936.9957 & 859.0994 & 936.1623 \\
\hline Elongation & 6.000362 & 13.66162 & 4.244219 & 0.214007 & 0.1114921 & 0.1813531 \\
\hline Elongation after break & 5.589775 & 13.18036 & 3.83329 & 0.1689866 & 0.0685821 & 0.1363553 \\
\hline Module (MPa) & 15264.85 & 5618.747 & 21564.12 & 437834.2 & 770547.6 & 516209.6 \\
\hline Energy (kJ) & 289.8 & 666.7 & 198.8 & 273.0 & 203.0 & 249.0 \\
\hline & \multicolumn{2}{|c|}{ Hardened nickel|| } & & Warm galvanizing \\
\hline Force (N) & 105175.5 & 92869.51 & 104662.2 & 106726.0 & 89014.71 & 106597.7 \\
\hline Extension (mm) & 5.002722 & 9.035047 & 3.14964 & 0.5088025 & 4.231294 & 0.4345179 \\
\hline Stress (MPa) & 929.9554 & 821.1467 & 925.4175 & 943.665 & 787.0629 & 942.5307 \\
\hline Elongation & 10.00544 & 18.07009 & 6.299279 & 1.017605 & 8.462587 & 0.8690357 \\
\hline Elongation after break & 9.98278 & 18.03479 & 6.276088 & 0.804564 & 8.260647 & 0.6560751 \\
\hline Module (MPa) & 9294.494 & 4544.231 & 14690.85 & 92733.91 & 9300.499 & 108457.1 \\
\hline Energy (kJ) & 520.5 & 933.7 & 325.9 & 56.0 & 431.2 & 48.1 \\
\hline \hline
\end{tabular}




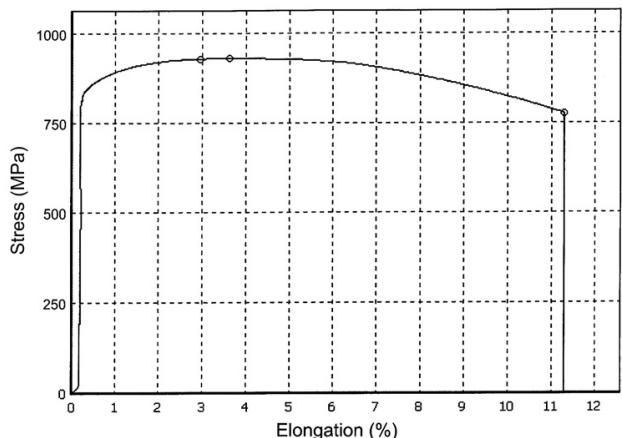

a

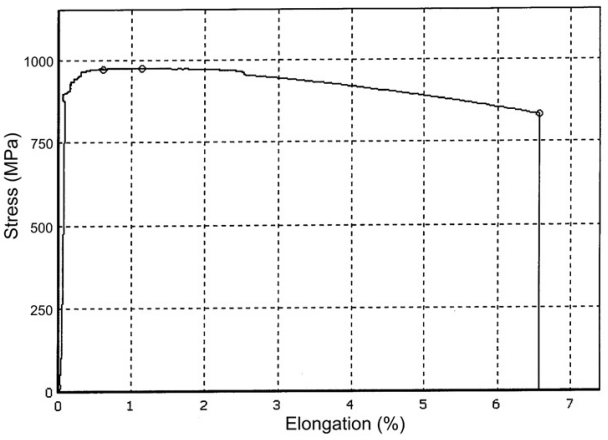

c

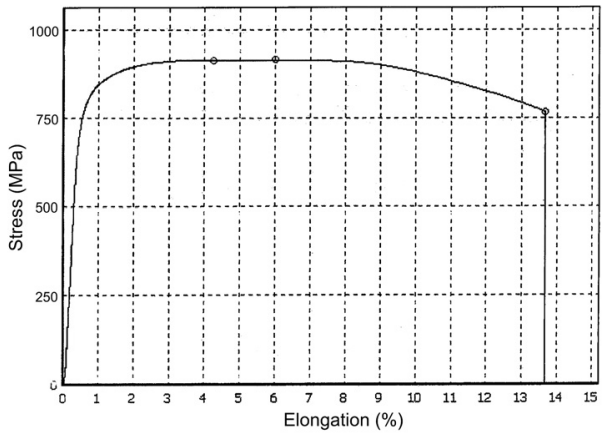

e

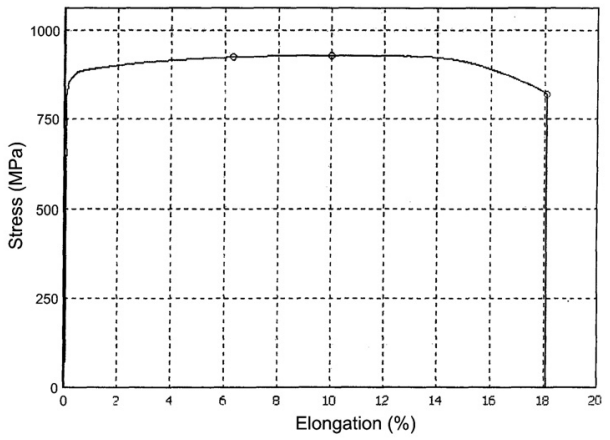

$\mathrm{g}$

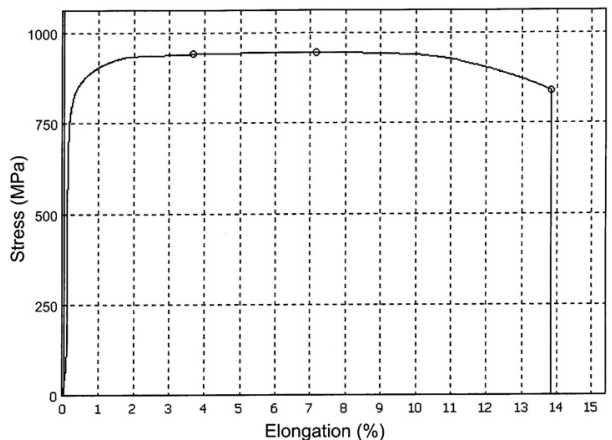

b

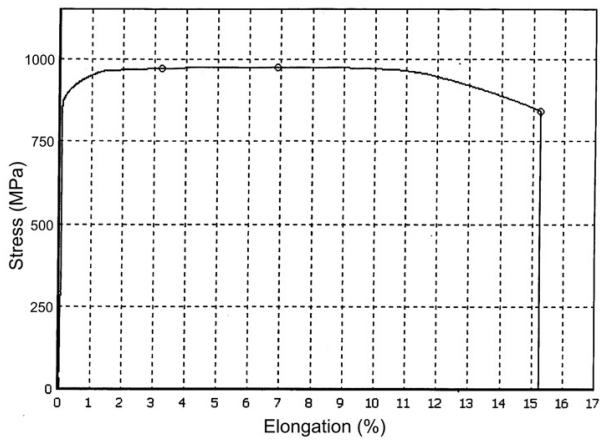

d

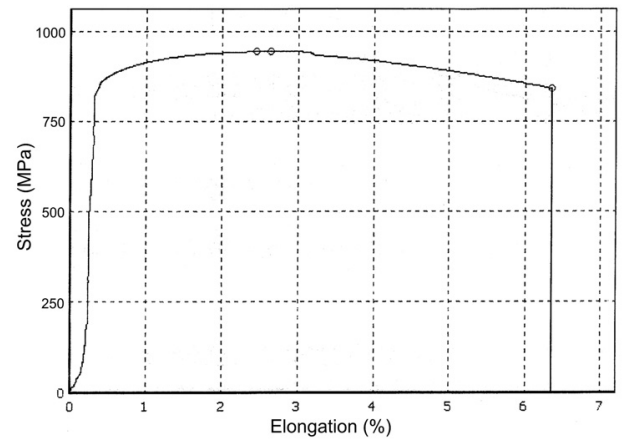

f

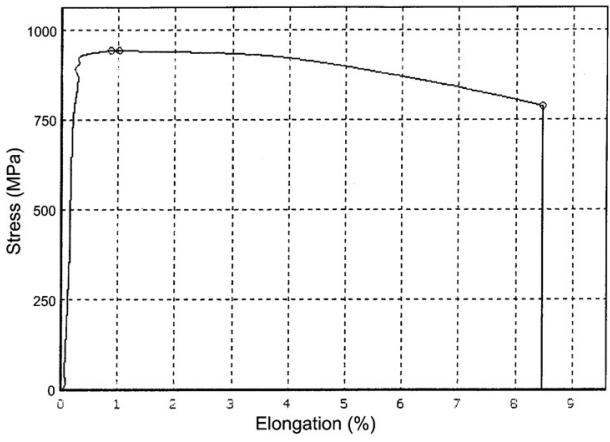

$\mathrm{h}$

Fig. 2. Force curves in term of length extension of components with 13 (a-d) and $19 \mu \mathrm{m}(\mathrm{e}-\mathrm{h})$ thicknesses: (a, e) trim chromium; (b, f) hardened chromium; (c, g) hardened nickel; (d, h) warm galvanization. 
2.2. The Test Conditions. Components for each group of analyzed coatings were made from CK45 steel according to the British Standard BS3518 for conducting fatigue tests, which specifies the recommended manufacturing methods for test specimens [7]. Test specimens with dimensions depicted in Fig. 3 are machined and subjected to surface treatment, and as the final step, the surface of specimens are polished by sandpaper No.600. The direction of polishing is along the length of the component, in order to minimize the surface roughness and make it smooth and glossy [4, 7].

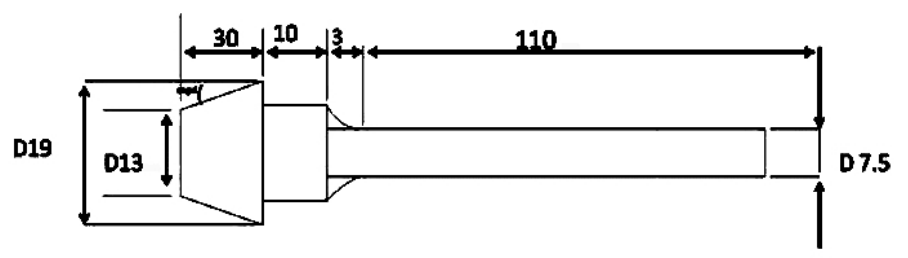

Fig. 3. A schematic of the fatigue test specimen [7]. (Dimensions in $\mathrm{mm}$.)

It is noteworthy that, in order to reduce the error percentage at the stage of preparing the components, they have been subjeted to rasping surface treatment, whereas dimensions of the blunt cones in the component edges described in Fig. 3 are controlled by Eq. (1):

$$
\tan (\alpha / 2)=\frac{D-d}{2 L},
$$

where $D$ is the larger-edge diameter of the blunt cone, $d$ is its smaller-edge diameter, and $L$ is the blunt cone length.

At the next stage, using the process of plating, the analyzed coatings with the thickness of 13 and $19 \mu \mathrm{m}$ have been deposited under the same operation conditions, including temperature, humidity and other factors effective in the components [8].

Using the scanning electronic microscope (SEM), several photos with magnification of 1000 were taken, as it is shown in Fig. 4, in order to analyze the accuracy of plating of components and the thickness of coatings.

3. Testing Conditions. In this study, the most common type of fatigue test, Moore rotating beam under pure bending load, has been applied, the average stress being equal to zero; in other words, the stress range is twice the maximum stress [4].

The frequency of loading of test machine used is equal to $3500 \mathrm{rpm}$ and the tests at 4 different levels of applied load 107.91, 117.72, 122.625, and 124.578 N are conducted; and the averaged experimental results obtained at each level are introduced as the number of cycles to fracture at that level; and based on it, the first component of the $S-N$ curve (limited duration) of each of the analyzed coatings with a thickness of $13 \mu \mathrm{m}$ are obtained, as is shown in Fig. 5.

4. Finite Element Analysis. Fatigue analysis has traditionally been performed at a later stage of the design cycle. This is due to the fact that the loading information could only be derived from the direct measurement, which requires a prototype. Multibody dynamics is capable of predicting the component loads 


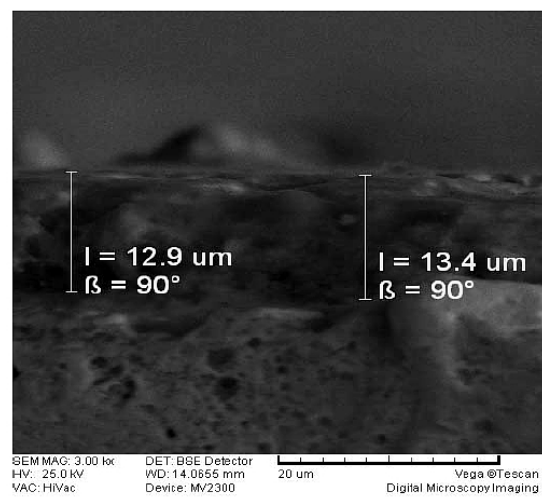

a

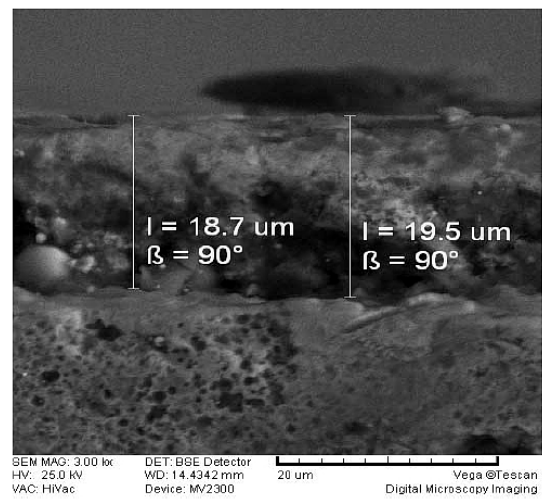

$\mathrm{b}$

Fig. 4. Imaging surface of coating at components by SEM: (a) thickness of coating is $13 \mu \mathrm{m}$; (b) thickness of coating is $19 \mu \mathrm{m}$.

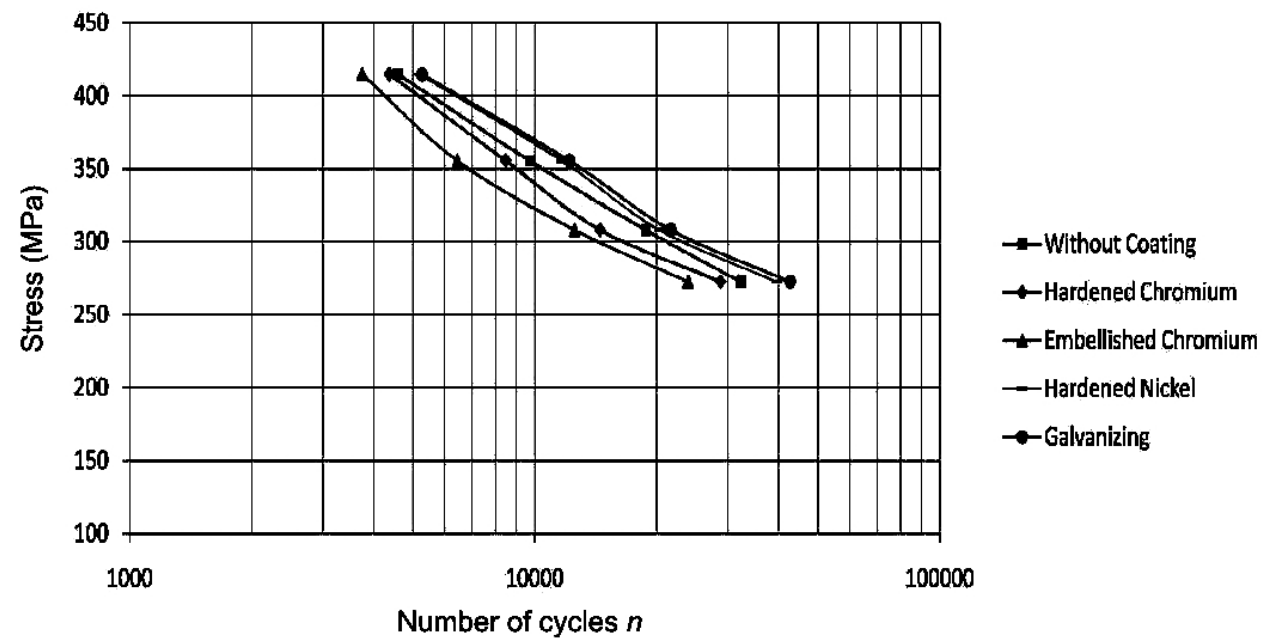

Fig. 5. $S-N$ curve of different coatings with the thickness of $13 \mu \mathrm{m}$ based on experimental data [6].

which enable a designer to undertake the fatigue assessment even before the prototype is fabricated. The purpose of analyzing a structure early in the design cycle is to reduce the development time and costs. This is achieved to determine the critical region of the structure and improving its design even before prototypes are produced and tested. The finite element method (FEM) based on fatigue analysis can be considered as a complete engineering analysis for the component. The fatigue life can be estimated for every element via FEM model, and the contour plots of life damage can be obtained. The geometry information is provided by the FEM result for each load case applied independently. The respective material properties are also provided for the aplied fatigue analysis method. An integrated approach to fatigue life analysis combines the multibody dynamic analysis, FEM analysis, and the fatigue analysis into a consistent entity for the prediction of fatigue life of a component. A flowchart of the FEM-based fatigue analysis is shown in Fig. 6 [9]. 


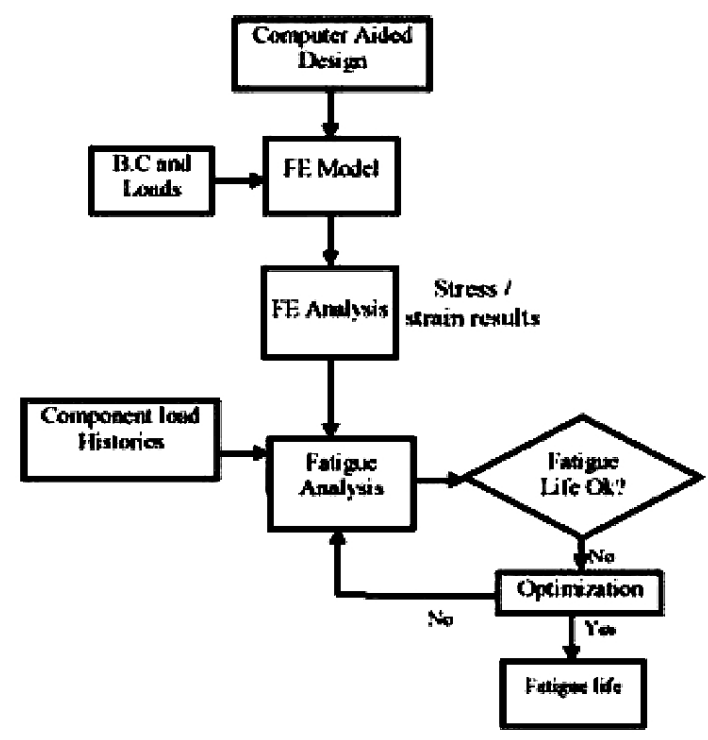

Fig. 6. The FEM-based fatigue analysis [9].

4.1. Earlier Introduced Finite Element Model. In the finite element model, which has been elaborated in 2011 within framework of the ANSYS software, two types of 3D elements, i.e., solid and shell ones, are used which are applied, respectively, for modeling the base steel, coating and the intermediate phase between them (having a smaller value thickness as compared to its length). In the new finite element model, including three separate phases, the base metal, coating and the interface between them are considered; whereas the mechanical properties of the interface, are treated as the average value of mechanical properties of the two adjoining phases [10-12].

In this model, by specifying the type of coating and the base metal, with this assumption, the mechanical properties of the intermediate phase can be easily assessed; while the thickness of intermediate phase is also considered to be equal to the length of the metallic bond between the atoms of the two adjoining phases.

4.2. A New Finite Element Model. The difference between the proposed model and earlier presented model is just in modeling the intermediate phase between the base metal and the coating. In the new model, a 3D linear spring element, which has the axial, bending and torsion stiffness, is used instead of shell element.

In the model, which describes $1 / 4$ part of the component in cylindrical coordinates, the number of nodes at the outer surface of the base metal is considered equal to the number of nodes at the interior surface of coating, while each of the nodes of the two levels are linked together by a spring element.

In order to assess the spring stiffness, firstly, the axial, bending and torsion stiffness of a solid cylindrical beam (base metal model) and a hollow cylindrical beam (coating model or, in other words, the deposited component) are obtained through engineering formulas [13]:

$$
K_{r}=\frac{A E}{L^{3}},
$$




$$
\begin{aligned}
& K_{\varnothing}=\frac{I G}{L}, \\
& K_{\theta}=E I .
\end{aligned}
$$

Then, specifying the stiffness of the two phases of the model in each of the categories of loading, applying a specific load in the lab, and measuring the total changes and using the rule of total effects, we can obtain the ratio of unknown phase transformation from the total changes based on the Fig. 7; and then the stiffness of intermediate phase can be calculated.

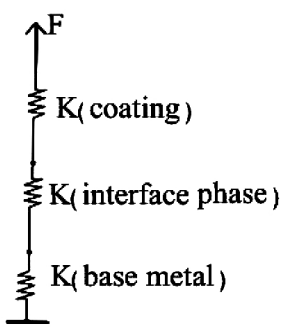

Fig. 7. A schematic of a solution for assessing the stiffness of the intermediate phase experimentally, based on stiffness of the other two phases.

One of the important issues that must be considered in the present finite element model is the length of a spring element used to model the intermediate phase between the base metal and the coating; so that specifying the two adjoining phases, the length of the metal bond of the atoms of the two adjoining phases is considered to be equal to the length of spring elements in the present model; as it is seen from the finite element model scheme depicted in Fig. 8.

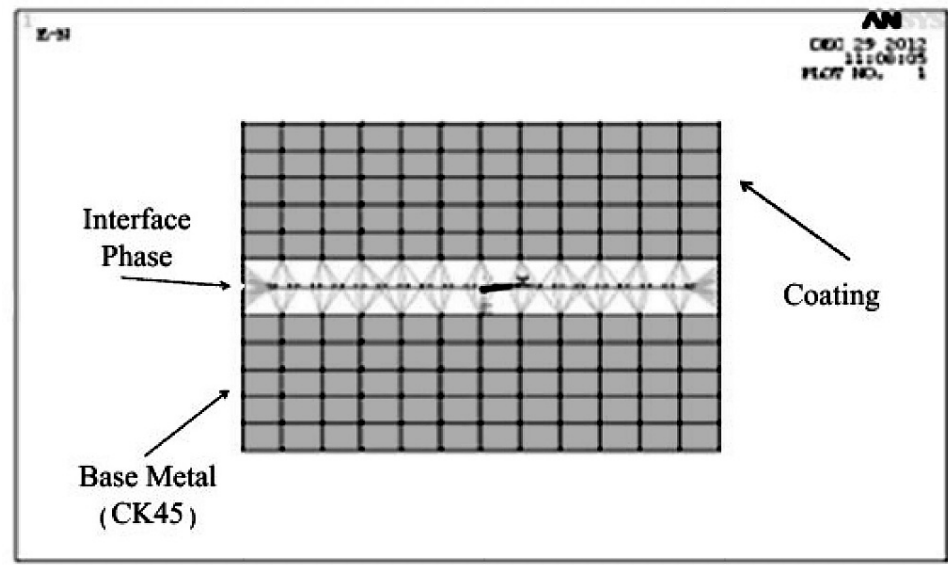

Fig. 8. FE model of the deposited components consisted of three independent phases in the ANSYS software.

$S-N$ curves obtained from fatigue analysis via the ANSYS software using the new finite element model of the coated components with coatings of 13 and $19 \mu \mathrm{m}$ thickness values are depicted in Fig. 9. 


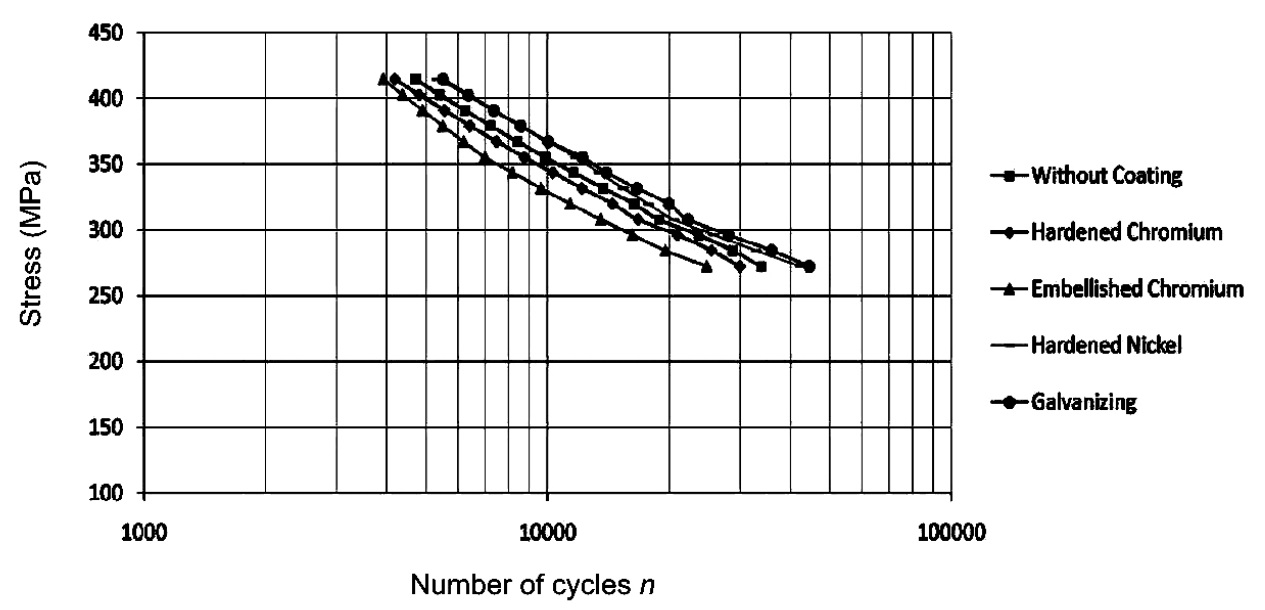

a

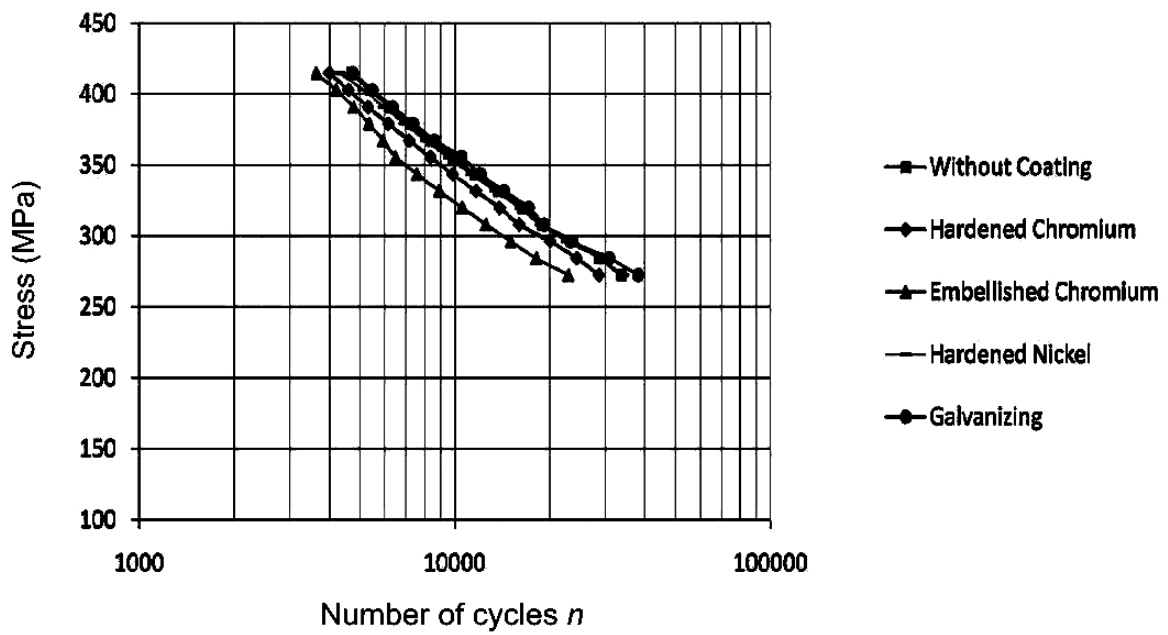

b

Fig. 9. $S-N$ curve obtained for components with a thickness of 13 (a) and $19 \mu \mathrm{m}$ (b) based on the extracted data of the software using the new FE model.

The observed difference between the results obtained from finite element analysis and experimental data is attributed to application of a linear spring element, while for better approximation and closer fit one can use a nonlinear spring element, and moreover, the spring constants coulb also be calculated using different theories of the potential energy. However, in this research, linear spring element has been used, in order to reach acceptable results with the minimal computation efforts (increasing the speed of solving the equations) and simplification of governing equations (using linear terms instead of nonlinear terms).

With account of the simplifications made, the results obtained from the experimental tests and finite element analysis (Figs. 6 and 7) indicate that, considering the environmental and operation conditions of components, a warmgalvanized coating with thickness less than $19 \mu \mathrm{m}$ is the most appropriate coating 


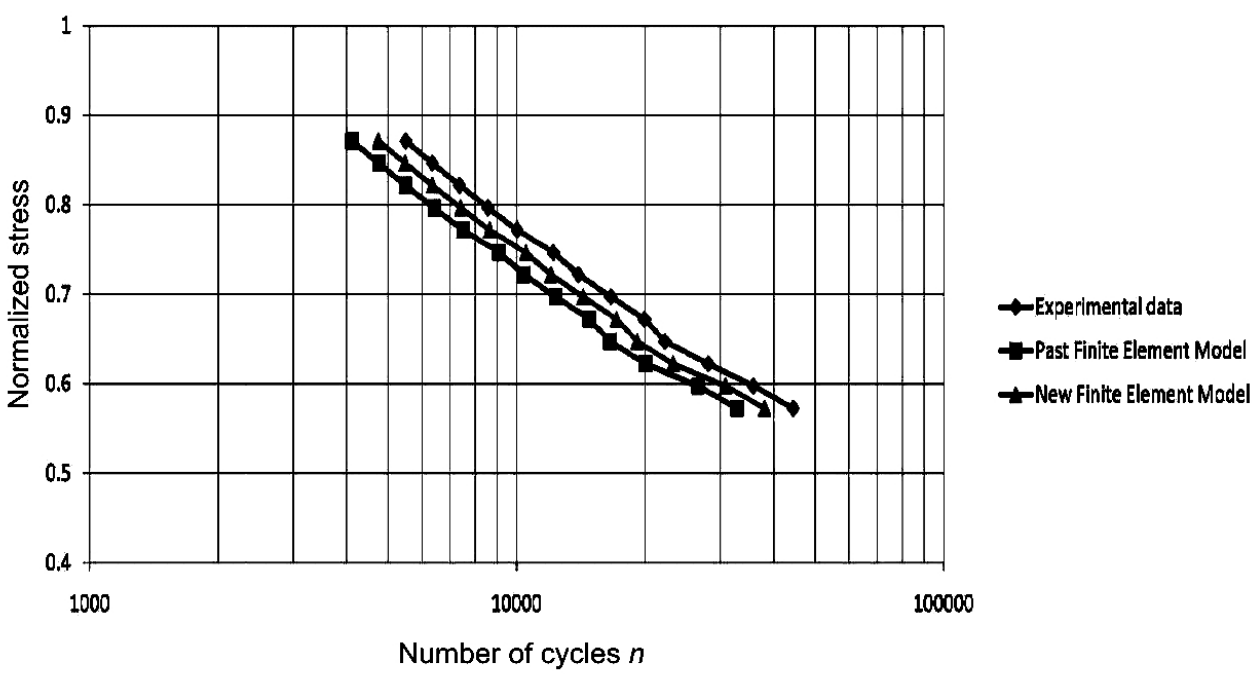

Fig. 10. Comparison of the $S-N$ curve of the warm-galvanized coating with a thickness of $13 \mu \mathrm{m}$ through different methods.

among the analyzed coatings. Consider the results of two finite element models and experimental data on the components with warm-galvanized coatings of $13 \mu \mathrm{m}$ in thickness, which are depicted in Fig. 10.

As it is seen from this plot, despite the fact that the results of a new finite element model and experimental data are different, their fit is improved, as compared to the earlier developed FEM model.

5. The Effect of Coating Thicknesses on the Fatigue Life of Components. As is seen from Fig. 9, with increased thickness the median between $S-N$ curves of the coatings decreases, so that it may be possible to shift curves corresponding to different coatings by increasing their thickness and even change their position to each other. In this respect, data on the reduction of fatigue life of components, as a result of increasing thickness from $6 \mu \mathrm{m}$ to higher values are given in Table 3 for various coatings.

In the previous section, warm-galvanized coating was introduced as the most appropriate, but according to Table 3, the rate/speed of reduction of the fatigue life of components, as a result of equal increase in thickness of various coatings, is much higher for the warm-galvanized coating than for hardened chromium coating.

The highest amount of iron in the $\gamma$-layer of galvanized coating (closest coating layer to the base metal) may be treated as a metallurgical reason for embrittlement of cladding due to the increased thickness of the coating. As the coating thickness increases, the amount of iron in the $\gamma$-layer increases, and it leads to higher brittleness of the layer. Therefore, the rate of fatigue life reduction is a result of high increase in thickness.

According to the data from Table 3, the lowest rate of fatigue life reduction is observed in hardened chromium coating; in case where the coating thickness increases to a certain level, the best cladding is the warm-galvanized coating, and then the hardened chromium coating is the most appropriate cladding. Therefore, we have thickness limitation for the use of warm-galvanized coating; while beyond 
The Reduction of Fatigue Life of Components with Different Coatings

for Increasing Thickness of $6 \mu \mathrm{m}$

\begin{tabular}{|c|c|}
\hline Type of Coating & Reduction in fatigue life, $\%$ \\
\hline Warm galvanizing & 20.62 \\
\hline Hardened chromium & 14.96 \\
\hline Embellished chromium & 7.42 \\
\hline Hardened nickel & 4.37 \\
\hline
\end{tabular}

the limitation the hardened chromium coating is the best choice for applications under the analyzed operation conditions.

Conclusions. Considering the fact that the number of conducted tests exceeds than the standard number, the conclusions are quite reliable, and the galvanized coating is shown to be the most appropriate coating, being erosion-, corrosion-, and fatigue-resistant for very small values of coating thickness (13 and $19 \mu \mathrm{m})$ under the specified conditions.

For the analyzed loading conditions of the component, galvanized coating is the best than other coatings with small thicknes values, while with increased thickness values, a galvanized coating beommes too brittle due to the high amount of iron in $\gamma$-layer, so that a hardened chrome coating should be used as the most appropriate coating, which is more resistant against erosion and corrosion under fatigue conditions.

However, the rate of reduction of the fatigue life under equal conditions of increasing the coating thickness is much higher for galvanized coatings, than for hardened chrome coatings. This is one of the reasons for using the hardened chrome coating in case of very high values of coating thickness.

More detailed calculations of this effect for galvanized coating require additional compuitation costs and efforts, and have yet to be performed,

Generally, hardened chrome coatings are used as the best protection against erosion and corrosion. However, in order to achieve the best performance and highest operational efficiency, the coating thickness should be determined based on the level of erosion and corrosion of the components, considering the operation conditions of the components, including the type and level of the applied load, parameters of corrosive environment, etc.

An finally, the linmited fatigue life and fatigue limit values should be assessed and, taking into account other parameters, such as cost, availability, etc., the most appropriate coating should be selected.

\section{Резиме}

Аналізується вплив промислових покриттів із зміцненого хрому, зносостійкого хрому та зміцненого нікелю, отриманих методом гарячого цинкування, на границю витривалості деталей. Зроблено спробу більш точно проаналізувати втому деталей за допомогою моделювання границі поділу між основним металом і покриттям, використовуючи при цьому пружні елементи. Прове- 
дено порівняння кривих утоми, отриманих описаним методом скінченноелементного моделювання (включаючи три різних фази) і відомими методами скінченноелементного моделювання, в яких для моделювання проміжної фази використовували елемент оболонки, 3 кривими утоми, побудованими за даними експериментальних досліджень. Результати показали, що дана модель $є$ удосконаленою порівняно 3 іншими моделями i дозволяє отримати більш надійні результати. 3 урахуванням умов оточуючого середовища й експлуатаційних умов як найбільш прийнятне покриття представлено тонке цинкове покриття. Зі значним збільшенням товщини покриття найкращим є зміцнене хромове покриття. Зі збільшенням товщини оцинкованих і зміцнених хромових покриттів на 6 мкм значення границі витривалості зменшується на 14,96 і 4,37\% відповідно.

1. R. I. Stefener and H. A. Fachs, Metal Fatigue in Engineering, Gilan University Publication (1998).

2. J. F. Luo, Y. J. Liu, and E. J. Berger, "Interfacial Stress analysis for multicoating systems using an advanced boundary element method," Comput. Mech., 24, 448-455 (2000).

3. C. Giummarra and H. R. Zonker, "Improving the fatigue response of aerospace structural joints," in: ICAF 2005 Proc., Hamburg, Germany (2005).

4. J. Lemaitre and R. Desmorat, Engineering Damage Mechanics: Ductile, Creep, Fatigue and Brittle Fracture, Springer, Heidelberg (2005).

5. Y. L. Lee, J. Pan, R. Hathaway, and M. Barkley, Fatigue Testing and Analysis: Theory and Practice, Elsevier, Boston (2005).

6. A. Arghavan, K. R. Kashyzadeh, and A. Amiri Asfarjani, "Investigating effect of industrial coatings on fatigue damage," J. Appl. Mech. Mater., 87, 230 (2011).

7. B. Khorshidi, Strength of Material Lab, University Book Publication (2004).

8. E. Besharat, Metals Coating Engineering, Tarrah Publication, Tehran (2005).

9. A. A. Asfarjani, S. Adibnazari, and K. R. Kashyzadeh, "Experimental and finite element analysis approach for fatigue of unidirectional fibrous composites," J. Appl. Mech. Mater., 87, 106 (2011).

10. H. Jahed Motlagh, ANSYS, Industry \& Science University (2000).

11. D. A. Hancq, Fatigue Analysis Using ANSYS, ANSYS Inc. (2003).

12. R. Browell and A. Hancq, Calculating and Displaying Fatigue Results (2006).

13. A. Timoshenko, Advanced Strength of Material, Ayizh Publ. (2001). 